\title{
Flavobacterium granuli sp. nov., isolated from granules used in a wastewater treatment plant
}

\author{
Correspondence \\ Sung-Taik Lee \\ e_stlee@kaist.ac.kr
}

\author{
Zubair Aslam, Wan-Taek Im, Myung Kyum Kim and Sung-Taik Lee
}

Department of Biological Sciences, Korea Advanced Institute of Science and Technology, 373-1, Guseong-dong, Yuseong-gu, Daejeon, 305-701, Republic of Korea
The genus Flavobacterium, which belongs to the CytophagaFlavobacterium-Bacteroides group, was proposed by Frankland in 1889 (Bergey et al., 1923). The formal description of the genus has been emended several times since then. At present, the genus comprises 28 species. Bernardet et al. (1996) proposed an amendment to the description, which states that the genus Flavobacterium represents predominantly gliding, pigmented bacteria that have menaquinone- 6 as the primary respiratory quinone. Species of the genus Flavobacterium have DNA G + C contents of 32-37 mol\%. Through emendation of classification, several species previously placed in the genus Flavobacterium have been reclassified and placed in new or different genera, including the genera Microbacterium (Takeuchi \& Hatano, 1998), Salegentibacter (McCammon \& Bowman, 2000) and Planococcus (Nakagawa et al., 1996). Several species previously placed in other genera, including Cytophaga and Flexibacter, have been reclassified and placed in the genus Flavobacterium (Bernardet et al., 1996). Flavobacterium species have been isolated from diverse habitats such as fresh and salt water, soil, sediment, sea ice, diseased fish and microbial mats.

Published online ahead of print on 14 January 2005 as DOI 10.1099/ ijs.0.63459-0.

Abbreviation: UASB, upflow anaerobic sludge blanket.

The GenBank/EMBL/DDBJ accession number for the $16 \mathrm{~S}$ rRNA gene sequence of strain $\mathrm{KwO5}^{\top}$ is $\mathrm{AB} 180738$.

Fatty acid profiles of strain $\mathrm{KWO}^{\top}$ and related type strains of Flavobacterium species are available as supplementary material in IJSEM Online.
Strain $\mathrm{Kw} 05^{\mathrm{T}}$ was isolated from granules used in the wastewater treatment plant of a beer-brewing factory in Kwang-Ju, Republic of Korea. Anaerobic granules are bacterial aggregates that result from the flocculation of sludge in an upflow anaerobic sludge blanket (UASB) reactor (de Zeeuw \& Lettinga, 1980). They are composed of micro-organisms, inorganic nuclei and extracellular polymers (Fukuzaki et al., 1991; Shen et al., 1993). Great attention has been paid to the internal structure and catalytic activities of these granules (MacLeod et al., 1990; Schmidt \& Ahring, 1996). In our laboratory, the relationship between the structure and resistance to toxic chemicals of anaerobic granules from a brewery wastewater treatment UASB reactor was studied (Bae \& Lee, 1999; Bae et al., 2000). In a series of studies, we attempted to isolate micro-organisms from the anaerobic granules in order to investigate the community structure based on a culture system. Interestingly, the granules contained aerobic bacteria even though they had been kept under anaerobic conditions for 2 years. Strain $\mathrm{Kw} 05^{\mathrm{T}}$ was one of the dominant bacterial isolates that was grown under aerobic conditions.

A polyphasic approach, including phylogenetic analysis based on 16S rRNA gene sequences, chemotaxonomic and phenotypic properties, was conducted to determine the precise taxonomic position of strain $\mathrm{Kw} 05^{\mathrm{T}}$. The results obtained indicated that it can be assigned as a member of the genus Flavobacterium, but it is clearly distinguished from recognized Flavobacterium species. Here, we propose $\mathrm{Kw} 05^{\mathrm{T}}$ as the type strain of a novel species, Flavobacterium granuli sp. nov. 
For isolation of aerobic bacteria, brownish black granules (around $2 \mathrm{~mm}$ in diameter) from a brewery wastewater treatment UASB reactor were homogenized using an Ace homogenizer (Nihonseiki Kaisha Ltd). The suspension was spread on R2A agar plates (Difco) after being serially diluted with $50 \mathrm{mM}$ phosphate buffer $(\mathrm{pH} 7 \cdot 0)$. The plates were incubated at $30^{\circ} \mathrm{C}$ for 2 weeks. Single colonies on the plates were purified by transferring them onto new plates and incubating again under the same conditions. The purified colonies were tentatively identified based on partial sequences of the $16 \mathrm{~S}$ rRNA gene. Strain $\mathrm{Kw} 05^{\mathrm{T}}$ was one of the dominant isolates that appeared on the plates following aerobic incubation.

Gram reaction was performed using the non-staining method as described by Buck (1982). Cell morphology was observed under a Nikon light microscope at $\times 1000$ magnification, with cells grown for 3 days at $30^{\circ} \mathrm{C}$ on $\mathrm{R} 2 \mathrm{~A}$ agar. Catalase and oxidase tests were performed by the procedures outlined by Cappuccino \& Sherman (2002). Substrate utilization as the sole carbon source and physiological characteristics were determined with API $32 \mathrm{GN}$, API 20E and API 20NE galleries according to the manufacturer's instructions (bioMérieux). Congo red absorption, presence of gliding motility (Bernardet et al., 2002), production of flexirubin-type pigments (Reichenbach, 1989), degradation of DNA [using DNA agar (Difco) supplemented with $0.01 \%$ toluidine blue (Merck)], degradation of casein, chitin, starch and L-tyrosine (Atlas, 1993), production of a brown diffusible pigment on L-tyrosine agar and precipitation on egg-yolk agar (Atlas, 1993) were also investigated; reactions were read after 5 days. Hydrolysis of carboxymethyl cellulose was tested as described by Ten et al. (2004). Growth at different temperatures and $\mathrm{pH}$ was assessed after 5 days of incubation. Salt tolerance was tested on R2A medium supplemented with $1-10 \%(\mathrm{w} / \mathrm{v}) \mathrm{NaCl}$ after 7 days of incubation. Duplicate antibiotic-sensitivity tests were performed using filter-paper discs containing the following:

Table 1. Selected characteristics of Flavobacterium granuli sp. nov. Kw0 $5^{\top}$ and its nearest phylogenetic neighbours within the genus Flavobacterium

Taxa: 1, Flavobacterium granuli $\mathrm{Kw}_{0} 5^{\mathrm{T}}$; 2, F. hydatis; 3, F. saccharophilum; 4, F. pectinovorum (data for taxa 2-4 are from Bernardet et al., 1996); 5, F. frigidarium (Humphry et al., 2001); 6, F. hibernum (McCammon et al., 1998); 7, F. limicola (Tamaki et al., 2003); 8, F. omnivorum; 9, F. xinjiangense (Zhu et al., 2003); 10, F. degerlachei; 11, F. frigoris; 12, F. micromati (Van Trappen et al., 2004). +, Positive; (+), positive, weak or delayed response; -, negative; V, variable among strains; ND, not defined. All species shown are negative for precipitate formation on egg-yolk agar, indole production and arginine dihydrolase activity and are positive for production of catalase and degradation of aesculin.

\begin{tabular}{|c|c|c|c|c|c|c|c|c|c|c|c|c|}
\hline Characteristic & 1 & 2 & 3 & 4 & 5 & 6 & 7 & 8 & 9 & 10 & 11 & 12 \\
\hline \multicolumn{13}{|l|}{ Growth on: } \\
\hline TSA & + & + & + & + & + & + & + & + & - & + & + & $(+)$ \\
\hline Nutrient agar & + & + & + & + & + & + & + & + & $(+)$ & + & - & + \\
\hline Growth at $25^{\circ} \mathrm{C}$ on agar & + & + & + & + & - & + & + & - & - & + & $(+)$ & $(+)$ \\
\hline Flexirubin-type pigment & - & + & + & + & - & + & - & - & - & - & - & - \\
\hline Congo red absorption & - & - & - & - & + & - & + & ND & ND & - & - & - \\
\hline Glucose utilization & + & + & + & + & + & + & + & + & + & + & + & - \\
\hline Acid produced aerobically from carbohydrate & - & + & + & + & - & + & - & - & - & - & - & - \\
\hline Oxidase production & + & $\mathrm{V}$ & - & + & + & - & + & + & + & + & + & + \\
\hline Urease & + & ND & ND & ND & - & - & + & - & - & - & - & - \\
\hline \multicolumn{13}{|l|}{ Degradation of: } \\
\hline Tyrosine & - & + & + & + & - & + & + & - & - & - & + & - \\
\hline Gelatin & - & + & + & + & + & + & + & - & + & - & - & - \\
\hline Casein & - & + & + & + & + & + & + & + & + & - & + & - \\
\hline Carboxymethyl cellulose & - & ND & + & + & - & - & - & + & - & - & - & - \\
\hline Agar & - & ND & + & - & - & - & + & $\mathrm{ND}$ & ND & - & - & - \\
\hline Pectin & ND & + & + & + & - & - & - & + & - & - & - & - \\
\hline Chitin & - & $(+)$ & - & + & - & - & - & + & + & - & - & - \\
\hline Alginate & ND & - & ND & + & - & - & - & $\mathrm{ND}$ & $\mathrm{ND}$ & - & - & - \\
\hline Starch & - & + & + & + & - & + & + & + & - & + & + & - \\
\hline DNA & - & + & - & + & - & + & - & - & - & - & - & - \\
\hline$\beta$-Galactosidase activity (ONPG) & + & + & + & + & - & + & - & + & - & - & - & - \\
\hline $\mathrm{H}_{2} \mathrm{~S}$ production & - & - & + & ND & - & - & - & - & + & - & - & - \\
\hline Nitrate reduction & - & + & + & + & - & + & - & + & - & - & $\mathrm{V}$ & - \\
\hline DNA G $+\mathrm{C}$ content $(\mathrm{mol} \%)$ & 36 & 34 & 33 & 35 & 35 & 36 & 35 & 35 & 34 & 34 & 34 & 33 \\
\hline
\end{tabular}


streptomycin $\left(5,10\right.$ and $\left.15 \mu \mathrm{g} \mathrm{ml}^{-1}\right)$ (Mast Diagnostics), tetracycline $\left(5,10\right.$ and $\left.15 \mu^{-1}\right)$, kanamycin $(1 \cdot 0,1 \cdot 5$ and $\left.2 \cdot 0 \mathrm{mg} \mathrm{ml}^{-1}\right)$ and ampicillin $\left(20,25\right.$ and $\left.30 \mu \mathrm{g} \mathrm{ml}^{-1}\right)$ (Sigma). Discs were placed on R2A plates containing cultured $\mathrm{Kw} 05^{\mathrm{T}}$ and were then incubated at $30{ }^{\circ} \mathrm{C}$ for 7 days. Growth was tested against various dissolved antibiotics in duplicate at three different concentrations. A discrete $\mathrm{Kw} 05^{\mathrm{T}}$ colony (grown at $30{ }^{\circ} \mathrm{C}$ on R2A medium) was then spread onto each plate. (Humphry et al., 2001). Physiological and biochemical characteristics of strain $\mathrm{Kw} 05^{\mathrm{T}}$ and related type strains of Flavobacterium species are summarized in Table 1.

Extraction of genomic DNA, PCR-mediated amplification of the 16S rRNA gene and sequencing of the purified PCR product were carried out according to Im et al. (2004). 16S rRNA gene sequences of related taxa were obtained from GenBank. Multiple alignments were performed using the CLUSTAL_X program (Thompson et al., 1997). Gaps were edited in the BIOEDIT program (Hall, 1999). Evolutionary distances were calculated using the Kimura two-parameter model (Kimura, 1983). The phylogenetic tree was constructed using a neighbour-joining method (Saitou \& Nei, 1987) in the MEGA 2 program (Kumar et al., 2001) with bootstrap values based on 1000 replications (Felsenstein, 1985) (Fig. 1).

The $\mathrm{G}+\mathrm{C}$ content of the chromosomal DNA was determined as described by Mesbah et al. (1989) using reversedphase HPLC. Quinones were extracted from cells grown on R2A broth (Difco) and analysed as described by Komagata \& Suzuki (1987) using reversed-phase HPLC. Cellular fatty acids were analysed in organisms grown on trypticase soy agar (TSA; Difco) for 2 days. Cellular fatty acids were saponified, methylated and extracted according to the protocol of the Sherlock Microbial Identification System (MIDI). The fatty acids analysed by GC (Hewlett Packard 6890) were identified using the Microbial Identification software package (Sasser, 1990).

Cells of strain $\mathrm{Kw} 05^{\mathrm{T}}$ are aerobic, Gram-negative and rodshaped. Movement via flagella was not observed. Colonies grown on R2A agar plates (Difco) for 2 days were smooth, circular, non-glossy, yellow in colour and $2-4 \mathrm{~mm}$ in diameter. On R2A agar, strain $\mathrm{Kw} 05^{\mathrm{T}}$ was able to grow at $15-30{ }^{\circ} \mathrm{C}$ but not at 4 or $45^{\circ} \mathrm{C}$. Physiological characteristics of strain $\mathrm{Kw} 05^{\mathrm{T}}$ are summarized in the species description below and comparison of selective characteristics with related type strains of Flavobacterium species is given in Table 1.

The 16S rRNA gene sequence of strain $\mathrm{Kw} 05^{\mathrm{T}}$ was a continuous stretch of $1442 \mathrm{bp}$. Sequence similarity calculations based on a neighbour-joining analysis indicated that the closest relatives of strain $\mathrm{Kw} 05^{\mathrm{T}}$ were Flavobacterium limicola (96.6\%), Flavobacterium hibernum (96.3\%), Flavobacterium hydatis $(96 \cdot 1 \%)$ and Flavobacterium xinjiangense $(96 \cdot 1 \%)$. Lower sequence similarities $(<97 \cdot 0 \%)$ were found with all recognized species of the genus Flavobacterium. It has been suggested that in bacterial strains with less than 97\% 16S rRNA gene sequence similarity, levels of DNA-DNA hybridization are less than $70 \%$ (Stackebrandt \& Goebel, 1994), which defines a genomic species (Wayne et al., 1987). Thus, based on the $16 \mathrm{~S}$ rRNA gene sequence analysis, strain $\mathrm{Kw} 05^{\mathrm{T}}$ represents a novel species.

The G $+\mathrm{C}$ content of the genomic DNA of strain $\mathrm{Kw} 05^{\mathrm{T}}$ was $36 \cdot 2 \mathrm{~mol} \%$ and its major quinone was MK-6. The fatty acid profile of strain $\mathrm{Kw} 05^{\mathrm{T}}$ comprised iso- $\mathrm{C}_{15: 0}(28 \cdot 2 \%)$,

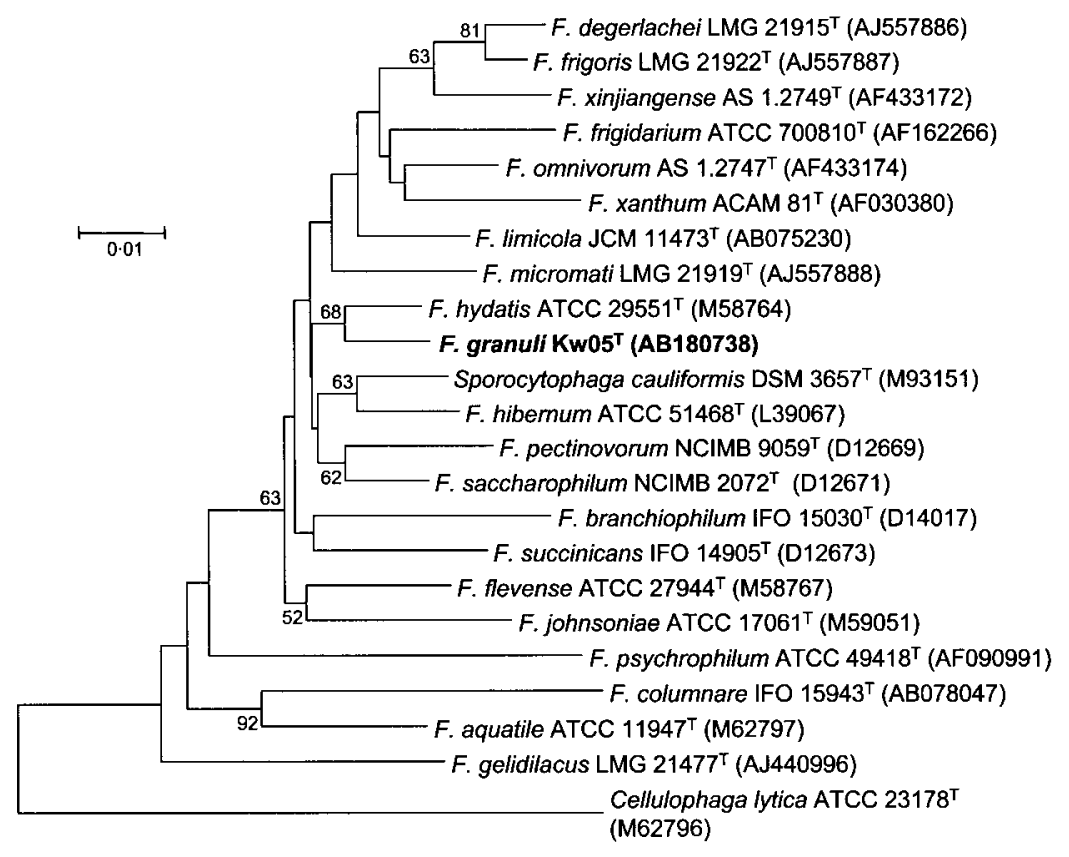

Fig. 1. Phylogenetic tree constructed from a comparative analysis of $16 \mathrm{~S}$ rRNA gene sequences showing the relationships of Flavobacterium granuli sp. nov. strain $\mathrm{Kw} 05^{\top}$ with related species. Bootstrap values (expressed as percentages of 1000 replications) greater than $50 \%$ are shown at the branch points. Bar, 0.01 substitutions per nucleotide position. 
iso- $\mathrm{C}_{17: 0} \quad 3-\mathrm{OH} \quad(11 \cdot 2 \%)$, iso- $\mathrm{C}_{15: 0} \quad 3-\mathrm{OH} \quad(10 \cdot 3 \%)$, iso- $\mathrm{C}_{17: 1} \omega 9 c(7 \cdot 5 \%), \mathrm{C}_{15: 1} \omega 6 c(5 \cdot 6 \%), \mathrm{C}_{15: 0}(5 \cdot 0 \%)$, iso- $\mathrm{C}_{15: 1} \mathrm{G}(4 \cdot 5 \%)$, unknown $13 \cdot 566(4 \cdot 3 \%), \mathrm{C}_{17: 1} \omega 6 c$ $(4 \cdot 1 \%)$, anteiso- $\mathrm{C}_{15: 0}(3 \cdot 1 \%)$, iso- $\mathrm{C}_{13: 0}(2 \cdot 9 \%)$, summed feature $4\left(\mathrm{C}_{16: 1} \omega 7 c /\right.$ iso- $\left.\mathrm{C}_{15: 0}-2 \mathrm{OH}, 2 \cdot 76 \%\right)$, summed feature 5 (anteiso- $\mathrm{C}_{17: 1} \mathrm{~B} / \mathrm{I}, 2 \cdot 2 \%$ ), iso- $\mathrm{C}_{16: 0} 3-\mathrm{OH}(1 \cdot 6 \%)$, $\mathrm{C}_{16: 0}(1 \cdot 42 \%)$, iso- $\mathrm{C}_{14: 0}(1 \cdot 0 \%), \mathrm{C}_{17: 1} \omega 8 c(1 \cdot 0 \%)$ and $\mathrm{C}_{18: 0}(1 \cdot 0 \%)$. No significant differences in the fatty acid profiles for the other Flavobacterium species were found, except that some strains have $\mathrm{C}_{16: 1} \omega 7 c$ as a major component. The fatty acid profiles of strain $\mathrm{Kw} 05^{\mathrm{T}}$ and related type strains of Flavobacterium species are available as supplementary material in IJSEM Online.

The results of our polyphasic analysis support the recognition of a novel species within the genus Flavobacterium, for which the name Flavobacterium granuli sp. nov. is proposed.

\section{Description of Flavobacterium granuli sp. nov.}

Flavobacterium granuli (gra.nu'li. L. gen. n. granuli of a small grain, pertaining to a granule, from which the type strain was isolated).

Cells are aerobic, Gram-negative, rod-shaped, non-motile and non-gliding (i.e. non-flagellated), $0 \cdot 3-0 \cdot 5 \mu \mathrm{m}$ wide by $2 \cdot 0-5 \cdot 0 \mu \mathrm{m}$ long. Colonies grown on R2A are circular, convex and yellow-coloured: flexirubin-type pigments are not detected. Congo red is not absorbed. Temperature range for growth is $15-37^{\circ} \mathrm{C}$; no growth occurs at $45^{\circ} \mathrm{C}$. Optimum temperature for growth is $25-30{ }^{\circ} \mathrm{C}$. Growth occurs in the absence of $\mathrm{NaCl}$ and in the presence of $1.0 \%$ (w/v) $\mathrm{NaCl}$, but not more than $2 \%(\mathrm{w} / \mathrm{v}) \mathrm{NaCl}$. Catalaseand oxidase-positive and strictly heteroorganotrophic. Cannot grow anaerobically. $\mathrm{H}_{2} \mathrm{~S}$ is not produced. Nitrate is not reduced to nitrite. No precipitation is produced on egg-yolk agar. Urease, $\beta$-glucosidase and $\beta$-galactosidase are positive. Acetoin is produced. Arginine dihydrolase, lysine decarboxylase, ornithine decarboxylase, tryptophan deaminase, gelatinase and citrate utilization are negative. Does not produce any acid or gas from glucose. Casein, xylan, chitin, DNA, tyrosine, carboxymethyl cellulose, gelatin and starch are not degraded. The following are utilized as sole carbon sources: glucose, mannose, $N$-acetylglucosamine, maltose, propionate and L-proline. The following are not utilized as sole carbon sources: L-arabinose, mannitol, gluconate, caprate, adipate, malate, citrate, phenylacetate, salicin, D-melibiose, L-fucose, D-sorbitol, valerate, histidine, 2-ketogluconate, 3-hydroxybutyrate, 4-hydroxybutyrate, rhamnose, D-ribose, inositol, D-sucrose, itaconate, suberate, malonate, acetate, lactate, L-alanine, 5-ketogluconate, glycogen, 3-hydroxybenzoate and L-serine. Resistant to $20 \mu \mathrm{g}$ ampicillin $\mathrm{ml}^{-1}, 15 \mu \mathrm{g}$ tetracycline $\mathrm{ml}^{-1}$ and $15 \mu \mathrm{g}$ streptomycin $\mathrm{ml}^{-1}$, and sensitive to $0.5 \mathrm{mg}$ kanamycin $\mathrm{ml}^{-1}$. Major cellular fatty acids are iso- $\mathrm{C}_{15: 0}(28 \cdot 2 \%)$, iso$\mathrm{C}_{17: 0} 3-\mathrm{OH}(11 \cdot 2 \%)$, iso- $15: 03-\mathrm{OH}(10 \cdot 3 \%)$ and iso$\mathrm{C}_{7: 1} \omega 9 c(7 \cdot 5 \%)$. The $\mathrm{G}+\mathrm{C}$ content of the genomic DNA of the type strain is $36 \cdot 2 \mathrm{~mol} \%$ (as determined by HPLC).
The type strain, $\mathrm{Kw}_{05} 5^{\mathrm{T}}\left(=\mathrm{KCTC} 12201^{\mathrm{T}}=\mathrm{IAM} 15099^{\mathrm{T}}\right)$, was isolated from granules used in the wastewater treatment plant of a beer-brewing factory in Kwang-Ju, Republic of Korea.

\section{Acknowledgements}

This work was supported by the 21C Frontier Microbial Genomic and Applications Center Program, Ministry of Science and Technology, grant MG02-0101-001-2-2-0.

\section{References}

Atlas, R. M. (1993). Handbook of Microbiological Media. Edited by L. C. Parks. Boca Raton, FL: CRC Press.

Bae, J.-W. \& Lee, S.-T. (1999). Layered structure of UASB granules gives microbial population resistance to toxic chemicals. Biotechnol Lett 21, 159-162.

Bae, J.-W., Rhee, S.-K., Hyun, S.-H., Kim, I. S. \& Lee, S.-T. (2000). Layered structure of granules in upflow anaerobic sludge blanket reactor gives microbial populations resistance to metal ions. Biotechnol Lett 22, 1935-1940.

Bergey, D. H., Harrison, F. C., Breed, R. S., Hammer, B. W. \& Huntoon, F. M. (editors) (1923). Bergey's Manual of Determinative Bacteriology. Baltimore: Williams \& Wilkins.

Bernardet, J.-F., Segers, P., Vancanneyt, M., Berthe, F., Kersters, K. \& Vandamme, P. (1996). Cutting a Gordian knot: emended classification and description of the genus Flavobacterium, emended description of the family Flavobacteriaceae, and proposal of Flavobacterium hydatis nom. nov. (basonym, Cytophaga aquatilis Strohl and Tait 1978). Int J Syst Bacteriol 46, 128-148.

Bernardet, J.-F., Nakagawa, Y. \& Holmes, B. (2002). Proposed minimal standards for describing new taxa of the family Flavobacteriaceae and emended description of the family. Int J Syst Evol Microbiol 52, 1049-1070.

Buck, J. D. (1982). Nonstaining (KOH) method for determination of Gram reactions of marine bacteria. Appl Environ Microbiol 44, 992-993.

Cappuccino, J. G. \& Sherman, N. (2002). Microbiology: a Laboratory Manual, 6th edn. Menlo Park, CA: Benjamin Cummings.

de Zeeuw, W. J. \& Lettinga, G. (1980). Use of anaerobic digestion for wastewater treatment. Antonie van Leeuwenhoek 46, 110-112.

Felsenstein, J. (1985). Confidence limit on phylogenies: an approach using the bootstrap. Evolution 39, 783-791.

Fukuzaki, S., Chang, Y. J., Nishio, N. \& Nagai, S. (1991). Characteristics of granular methanogenic sludges grown on lactate in a UASB reactor. J Ferment Bioeng 72, 465-472.

Hall, T. A. (1999). BIOEDIT: a user-friendly biological sequence alignment editor and analysis program for Windows 95/98/NT. Nucleic Acids Symp Ser 41, 95-98.

Humphry, D. R., George, A., Black, G. W. \& Cummings, S. P. (2001). Flavobacterium frigidarium sp. nov., an aerobic, psychrophilic, xylanolytic and laminarinolytic bacterium from Antarctica. Int J Syst Evol Microbiol 51, 1235-1243.

Im, W.-T., Bae, H.-S., Yokota, A. \& Lee, S.-T. (2004). Herbaspirillum chlorophenolicum sp. nov., a 4-chlorophenol-degrading bacterium. Int J Syst Evol Microbiol 54, 851-855.

Kimura, M. (1983). The Neutral Theory of Molecular Evolution. Cambridge: Cambridge University Press.

Komagata, K. \& Suzuki, K. (1987). Lipid and cell wall analysis in bacterial systematics. Methods Microbiol 19, 161-207. 
Kumar, S., Tamura, K., Jakobsen, I. B. \& Nei, M. (2001). MEGA2: molecular evolutionary genetics analysis software. Bioinformatics $\mathbf{1 7}$, 1244-1245.

MacLeod, F. A., Guiot, S. R. \& Costerton, J. W. (1990). Layered structure of bacterial aggregates produced in an upflow anaerobic sludge bed and filter reactor. Appl Environ Microbiol 56, 1598-1607.

McCammon, S. A. \& Bowman, J. P. (2000). Taxonomy of Antarctic Flavobacterium species: description of Flavobacterium gillisiae sp. nov., Flavobacterium tegetincola sp. nov. and Flavobacterium xanthum sp. nov., nom. rev. and reclassification of [Flavobacterium] salegens as Salegentibacter salegens gen. nov., comb. nov. Int J Syst Evol Microbiol 50, 1055-1063.

McCammon, S. A., Innes, B. H., Bowman, J. P., Franzmann, P. D., Dobson, S. J., Holloway, P. E., Skerratt, J. H., Nichols, P. D. \& Rankin, L. M. (1998). Flavobacterium hibernum sp. nov., a lactoseutilizing bacterium from a freshwater Antarctic lake. Int J Syst Bacteriol 48, 1405-1412.

Mesbah, M., Premachandran, U. \& Whitman, W. B. (1989). Precise measurement of the $\mathrm{G}+\mathrm{C}$ content of deoxyribonucleic acid by high-performance liquid chromatography. Int J Syst Bacteriol 39, 159-167.

Nakagawa, Y., Sakane, T. \& Yokota, A. (1996). Emendation of the genus Planococcus and transfer of Flavobacterium okeanokoites Zobell and Upham 1944 to the genus Planococcus as Planococcus okeanokoites comb. nov. Int J Syst Bacteriol 46, 866-870.

Reichenbach, H. (1989). Order I. Cytophagales Leadbetter 1974, 99 $9^{\mathrm{AL}}$. In Bergey's Manual of Systematic Bacteriology, vol. 3, pp. 2011-2013. Edited by J. T. Staley, M. P. Bryant, N. Pfennig \& J. G. Holt. Baltimore: Williams \& Wilkins.

Saitou, N. \& Nei, M. (1987). The neighbor-joining method: a new method for reconstructing phylogenetic trees. Mol Biol Evol 4, 406-425.

Sasser, M. (1990). Identification of bacteria by gas chromatography of cellular fatty acids. MIDI Technical Note 101. Newark, DE: MIDI Inc.

Schmidt, J. E. \& Ahring, B. K. (1996). Acetate and hydrogen metabolism in intact and disintegrated granules from an acetate-fed, $55^{\circ} \mathrm{C}$, UASC reactor. Biotechnol Bioeng 49, 229-246.
Shen, C. F., Kosaric, N. \& Blaszczyk, R. (1993). The effect of selected heavy metals ( $\mathrm{Ni}, \mathrm{Co}$ and $\mathrm{Fe}$ ) on anaerobic granules and their extracellular polymeric substance (EPS). Water Res 27, 25-33.

Stackebrandt, E. \& Goebel, B. M. (1994). Taxonomic note: a place for DNA-DNA reassociation and 16S rRNA sequence analysis in the present species definition in bacteriology. Int J Syst Bacteriol 44, 846-849.

Takeuchi, M. \& Hatano, K. (1998). Proposal of six new species in the genus Microbacterium and transfer of Flavobacterium marinotypicum ZoBell and Upham to the genus Microbacterium as Microbacterium maritypicum comb. nov. Int J Syst Bacteriol 48, 973-982.

Tamaki, T., Hanada, S., Kamagata, Y., Nakamura, K., Nomura, N., Nakano, K. \& Matsumura, M. (2003). Flavobacterium limicola sp. nov., a psychrophilic, organic-polymer-degrading bacterium isolated from freshwater sediments. Int J Syst Evol Microbiol 53, 519-526.

Ten, L. N., Im, W.-T., Kim, M.-K., Kang, M.-S. \& Lee, S.-T. (2004). Development of a plate technique for screening of polysaccharide-degrading microorganisms by using a mixture of insoluble chromogenic substrates. J Microbiol Methods 56, 375-382.

Thompson, J. D., Gibson, T. J., Plewniak, F., Jeanmougin, F. \& Higgins, D. G. (1997). The CLUSTAL_X Windows interface: flexible strategies for multiple sequence alignment aided by quality analysis tools. Nucleic Acids Res 25, 4876-4882.

Van Trappen, S., Vandecandelaere, I., Mergaert, J. \& Swings, J. (2004). Flavobacterium degerlachei sp. nov., Flavobacterium frigoris sp. nov. and Flavobacterium micromati sp. nov., novel psychrophilic bacteria isolated from microbial mats in Antarctic lakes. Int J Syst Evol Microbiol 54, 85-92.

Wayne, L. G., Brenner, D. J., Colwell, R. R. \& 9 other authors (1987). Report of the ad hoc committee on reconciliation of approaches to bacterial systematics. Int J Syst Bacteriol 37, 463-464.

Zhu, F., Wang, S. \& Zhou, P. (2003). Flavobacterium xinjiangense sp. nov. and Flavobacterium omnivorum sp. nov., novel psychrophiles from the China No. 1 glacier. Int J Syst Evol Microbiol 53, 853-857. 